\title{
Hemopneumothorax associated with pneumorrachis following blunt chest trauma
}

Putu Eka Mardhika', Tjokorda GB Mahadewa', Citra Aryanti ${ }^{2}$

'Department of Neurosurgery, Faculty of Medicine, Udayana University, Sanglah Hospital, Bali, Indonesia ${ }^{2}$ Department of General Surgery, Faculty of Medicine, Udayana University, Sanglah Hospital, Bali, Indonesia

\section{Cite this article:}

Mardhika PE, Mahadewa TGB, Aryanti C. Hemopneumothorax associated with pneumorrachis following blunt chest trauma. Neurologico Spinale Medico Chirurgico.2019;2(2): 33-36. DOI: $10.36444 /$ nsmc.v2i2. 10

Corresponding auther

Putu Eka Mardhika

Department of Neurosurgery, Faculty of Medicine Udayana University, Sanglah Hospital, Bali, Indonesia. ekamardhika@gmail.com

\section{Abstract}

Pneumorrhacis is a condition marked by the presence of air in the spinal canal. We present a rare case of pneumorrachis of the cervical to thoracic canal associated with hemopneumothorax and flail chest with subcutaneous emphysema that recovered remarkably after shaft clipping surgery and chest tube insertion only. Pneumorrachis can resolve by itself with conservative management. A 45-year-old woman suffered from chest pain and shortness of breath after fell at the hotel swimming pool. Further examination revealed rhonchi on left lung auscultation and asymmetry respiratory pattern. Computed tomography of the chest proved the presence of multiple rib fractures 4-9 left side, hemopneumothorax, subcutaneous emphysema. Accidentally, the CT showed intraspinal gas representing pneumorrachis extending from C6-T3. No neurologic deficit was found. She was treated conservative by supplemental oxygen only, no further neurological deterioration was detected. Follow up examination was uneventful and the symptoms resolved completely. Pneumorrachis was mostly found accidentally with a variety of underlying diseases, especially in the case of traumatic pneumothorax and fracture of the skull base. Pneumorrachis was

managed conservatively and should be taken in attention in the presence of neurologic deficits.

\section{Keywords: ribs fracture, pneumothorax, pneumorrachis \\ Keywords: ribs, fracture, pneumothorax, pneumorrachis}

\section{Introduction

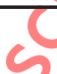

Pneumorrhacis is a condition marked by the presence of air in the spinal canal. It was Gordon et al., in 1988, who stated clearly the term of pneumorrachis as the presence of intraspinal air. ${ }^{1}$ It ean be associated with trauma or non-trauma cases. ${ }^{2}$ Usually, it is not associated with neurological deficit and not dangerous for the patient. It is usually found accidentally during a radiological examination. There is no established guideline for its treatment yet. ${ }^{3}$

Hemopneumothorax is a relatively common complication of multiple ribs fracture because of blunt chest trauma. The fracture of ribs can tear several blood vessels and cause blood accumulation in intrathoracic cavity. ${ }^{4-5}$ However, blunt chest trauma associated with pneumorrachis is a rare entity. ${ }^{1-3}$ It is still unclear how free air can trap in the spinal canal because of chest injury. ${ }^{6-8}$ In this article, we present a rare case of pneumorrachis of the cervical to thoracic vertebra canal, associated with hemopneumothorax and flail chest. We will discuss the possible mechanism of how free air can be trapped inside the spinal canal after blunt chest trauma. This case report is arranged based on the Surgical Case Report (SCARE) criteria.

\section{Case Report}

A 45-year-old woman with a history of left side multiple rib fractures with hemopneumothorax after fell at the hotel swimming pool. Vital sign examination found blood pressure $96 / 64$ $\mathrm{mmHg}$, respiratory rate 28 times/minute, heart rate 92 times per minute, $\mathrm{O}_{2}$ saturation $98 \%$ on 
10 liters/minute on a non-rebreathing mask. General physical examination revealed rhonchi on auscultation of left lung and asymmetry respiratory pattern or flail chest. Neurologic examination was normal. There was no sign of lateralization with perfect motoric and sensory status.

Computed tomography of the chest showed multiple rib fractures of 4th to 9th costae of the left side, hemopneumothorax, subcutaneous emphysema and pneumorrachis extending from C6 -T3 (Figure 1A, 1B, 2A). The patient undergone shaft clipped on 4th to 9th costaes of left ribs and chest tube placement by a thoracic surgeon (Figure 2B). Pneumorrachis was treated conservative by supplemental oxygen only, no further neurological deterioration was detected. The patient was discharged on day $14^{\text {th }}$ with complete recovery.

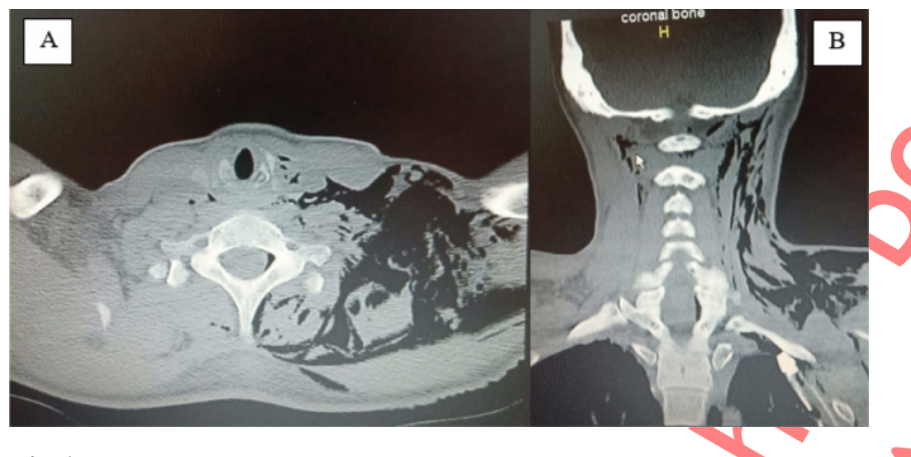

Fig 1. (A) Cervical CT Scan (axial view) and (B) coronal view showing subcutaneous emphysema on the left side and pneumorrachis intracanal of C7-T1

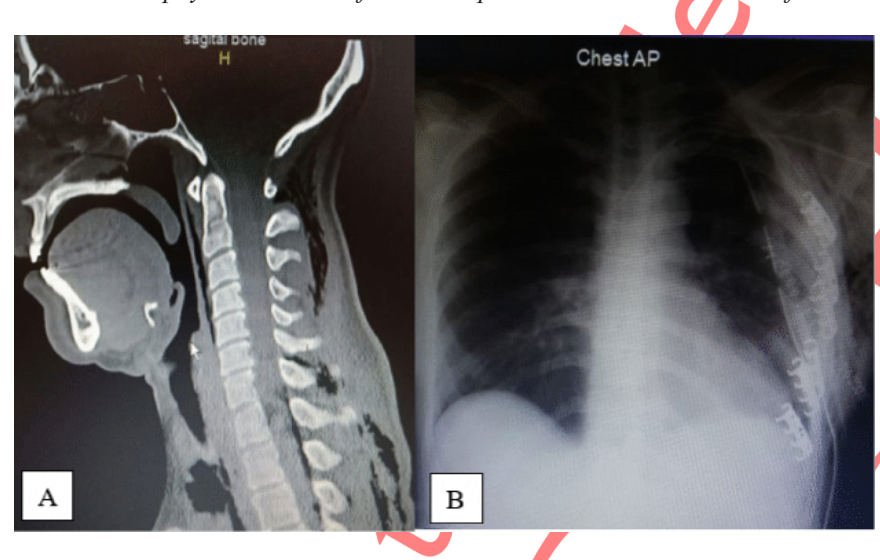

Fig 2. (A) Sagittal view showing pneumorrachis extending from C6 - T3. (B) Post shaft clipping surgery of left 4 - 9 ribs and chest tube insertion

\section{Discussion}

Pneumorrachis is defined as free air in the spinal canal, resulting from chest trauma, head trauma, epidural injections, spinal surgery, endoscopic retrograde cholangiopancreatography (ERCP) and/or occurred iatrogenically. Pneumorrachis had several definitions (pneumocele, pneumatosis, emphysema, aerorachia, pneumosaccus, air myelogram) before Gordon and Hardman (1977) describe the fixed term "pneumorrachis". About less than 80 case reports have been published worldwide, while many articles are not available online and not all were caused by traumatic pneumothorax (Table 1). 1,3,7-19

Pneumorrachis can be classified into internal and external. The internal pneumorachis is defined as the finding of air in the intradural space (subdural or subarachnoid), while the external pneumorachis is defined as the finding of air in the extradural space (intraspinal and epidural). ${ }^{2,13}$ In the extradural type, the absence of fascial barrier between the posterior mediastinum and neck causes migration of air from intervertebral foramina into the spinal canal. ${ }^{20-22}$ In intradural type, air dissects the interstitial space which surrounding the nerves and vessels through neural foramina or neurovascular sheaths. ${ }^{23}$ Specifically in pneumothorax, the marked increase in intra-alveolar pressure could cause alveolar rupture, which allows the air to pass along the bronchovascular axis up to the mediastinum. 16 The air the travelled along mediastinal pleura, then intervertebral foramina, and enter the dural space. ${ }^{24}$ The leakage of gas to the spinal canal can result in the negative pressure intradiscal, which could lead to further recruitment of gas in the disc space. ${ }^{25}$ Moreover, presented air in the spinal canal can move to the cranium, thus leading to pneumocephalus, ${ }^{26}$

2 The most common location for pneumorrachis to occur was at cervical, followed by thoracic, lumbar, then sacral. ${ }^{9}$ However, the location of air accumulation in spinal canal depends on the site, rate, and volume of air dissection, also the positioning of the patient. If free air was found at intradural, the pathomechanism usually was more severe, while if the air was only located extradural, the patient was usually better preserved elinically, and was usually not associated with pneumocephalous. The extradural air was often reabsorbed to the deeper structure. ${ }^{27}$ The symptomatic case could cause spinal cord compression, mostly in trauma cases.

Pneumorrachis ís primarly a radiographic diagnosis since it usually provide no specific clinical symptoms. The standardized treatment guideline was not existed until now. Patients with pneumorrhacis are usually managed conservative with cervical collar and supplemental oxygen showed promising results, even in the case with complicaiton. ${ }^{11}$ Oxygen therapy was used with the concept that oxygen induces air absorption, as previously reported..$^{28}$ The presence of intracranial injuries was suggested to have antibiotics prescription to prevent secondary infection. ${ }^{3}$ In fact, the treatment was primarily aimed at addressing the primary disease. ${ }^{2}$

Based on our analysis, the presence of pneumorrachis usually accompanied by calvaria or skull base fracture. As we can see in Table 1 , all the reported pneumorrachis case were accompany by pneumocephalus. The etiology of all case were either calvaria, skull base, sinus fracture, or combination of them. The fracture line may provide entry point for free air and manifest as pneumocephalus. The pneumocephalus somehow make their way into the spinal canal and manifest as pneumorrachis. However, in this case, the patient had blunt chest injury and accidentaly we found pneumorrachis from CT scan examination. Several authors have reported 6 similar case of pneumorrachis following blunt chest trauma but there is no further explanation about it. ${ }^{19}$ There were others 5 cases about pneumorrachis with pneumothorax as its underlying cause, however, no full text was available online. The intraspinal gas has the same low CT scan density with other gases must be clearly differentiated from gas 
Table 1. Published case reports of pneumorrachis occurred due to a traumatic fracture of brain skull and traumatic pneumothorax

\begin{tabular}{|c|c|c|c|c|c|c|}
\hline Author & MOI & Etiology & Location & Symptoms & Treatment & Outcome \\
\hline \multicolumn{7}{|c|}{ Associated with traumatic fracture of brain skull } \\
\hline $\begin{array}{l}\text { Gordon et al. } \\
\quad(1977)^{1}\end{array}$ & $\begin{array}{l}\text { Motor vehicle } \\
\text { accident }\end{array}$ & Open skull fracture & $\begin{array}{c}\text { Pneumocephalus andc= } \\
\text { pneumorrachis of the } \\
\text { cervical region }\end{array}$ & Decerebrate & Details not available & Death \\
\hline $\begin{array}{l}\text { Yip, et al. } \\
(1990)^{7}\end{array}$ & $\begin{array}{l}\text { Motor vehicle } \\
\text { accident }\end{array}$ & $\begin{array}{l}\text { Bifrontal and frontal sinus } \\
\text { fractures }\end{array}$ & $\begin{array}{c}\text { Pneumocephalus and } \\
\text { pneumorrachis of the } \\
\text { cervical }\end{array}$ & None & Antibiotics & Resolution \\
\hline $\begin{array}{c}\text { Sinha and } \\
\text { Mantle }(2000)^{8}\end{array}$ & $\begin{array}{l}\text { Motor vehicle } \\
\text { accident }\end{array}$ & $\begin{array}{l}\text { Multiple skull base } \\
\text { fractures, intracerebral } \\
\text { hemorrhage, otorrhea }\end{array}$ & $\begin{array}{c}\text { Pneumocephalus and } \\
\text { pneumorrachis of the } \\
\text { cervical }\end{array}$ & Coma & port & Death \\
\hline $\begin{array}{l}\text { Inamasu, et al. } \\
\qquad(2002)^{9}\end{array}$ & $\begin{array}{l}\text { Motor vehicle } \\
\text { accident }\end{array}$ & $\begin{array}{c}\text { Temporal bone fracture and } \\
\text { dural tear }\end{array}$ & $\begin{array}{c}\text { Pneumocephalus and } \\
\text { pneumorrachis of the } \\
\text { cervical }\end{array}$ & None & drainage & Resolution \\
\hline $\begin{array}{l}\text { Çayli, et al. } \\
\quad(2003)^{10}\end{array}$ & Fall/Trauma & $\begin{array}{c}\text { Mastoid fracture with } \\
\text { otorrhea }\end{array}$ & $\begin{array}{c}\text { Pneumocephalus and } \\
\text { pneumorrachis of the } \\
\text { cervical }\end{array}$ & & $\begin{array}{l}\text { Antibiotics and lumbar } \\
\text { drainage }\end{array}$ & Resolution \\
\hline $\begin{array}{l}\text { Yousaf, et al. } \\
\qquad(2003)^{11}\end{array}$ & Fall & $\begin{array}{l}\text { Temporal bone fracture and } \\
\text { epidural hematoma }\end{array}$ & $\begin{array}{l}\text { Pneumocephalus and } \\
\text { pneumorrachis of the } \\
\text { cervical }\end{array}$ & & Collar brace & Resolution \\
\hline $\begin{array}{l}\text { Chibbaro, et } \\
\text { al. }(2005)^{12}\end{array}$ & $\begin{array}{l}\text { Motor vehicle } \\
\text { accident }\end{array}$ & Mastoid cavity fracture & $\mathrm{Pn}$ & None & None & Resolution \\
\hline $\begin{array}{l}\text { Chaichana, et } \\
\text { al. }(2010)^{3}\end{array}$ & $\begin{array}{l}\text { Motor vehicle } \\
\text { accident }\end{array}$ & $\begin{array}{l}\text { Bilateral mastoid and } \\
\text { sphenoid wing fractures }\end{array}$ & $\begin{array}{l}\text { nocephalus and } \\
\text { norrachis of the }\end{array}$ & None & Antibiotics and oxygen & Resolution \\
\hline $\begin{array}{l}\text { Arora, et al. } \\
(2011)^{13}\end{array}$ & Assault & $\begin{array}{l}\text { Fracture of the cribrif } \\
\text { plate of ethmoid bo }\end{array}$ & 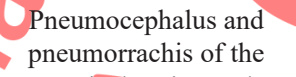 & e & biotics and oxygen & Resolution \\
\hline \multicolumn{7}{|c|}{ Associated with pneumothorax } \\
\hline $\begin{array}{l}\text { Yanagawa et } \\
\text { al. }(2007)^{14}\end{array}$ & $\begin{array}{l}\text { Automobile } \\
\text { accident }\end{array}$ & $\begin{array}{l}\text { Ribs fracture, extremities } \\
\text { bone fractures, cervical } \\
\text { root avulsion injury, } \\
\text { pneumomediastinum }\end{array}$ & Pneumorrachi & Loss of & $\begin{array}{l}\text { Artifical ventilation } \\
\quad \text { (intubation) }\end{array}$ & Resolution \\
\hline $\begin{array}{l}\text { Pangtey et al. } \\
\qquad(2008)^{15}\end{array}$ & Barotrauma & $\begin{array}{l}\text { Spontaneous pneumothorax } \\
\text { and pneumomediastinum }\end{array}$ & $\begin{array}{l}\text { Pneumocephalus and } \\
\text { pneumorrachis of the } \\
\text { lunbal (L2-3) }\end{array}$ & $\begin{array}{l}\text { Chest tightness } \\
\text { and shortness } \\
\text { of breath }\end{array}$ & None & Resolution \\
\hline $\begin{array}{l}\text { Ould-Slimane } \\
\text { et al. }(2010)^{16}\end{array}$ & $\begin{array}{l}\text { Motor vehicle } \\
\text { accident }\end{array}$ & $\begin{array}{l}\text { Pneumothorax, } \\
\text { pneumomediastinum, T7-8 } \\
\text { transverse process fracture }\end{array}$ & $\begin{array}{l}\text { Pneumocephalus and } \\
\text { pneumorrachis of the } \\
\text { thoracal region T7-8 }\end{array}$ & $\begin{array}{l}\text { Verterbral } \\
\text { pain, } \\
\text { neurological } \\
\text { deficits }\end{array}$ & $\begin{array}{c}\text { Spinal osteosynthesis and } \\
\text { oxygen }\end{array}$ & Resolution \\
\hline $\begin{array}{l}\text { Botchu et al. } \\
\qquad(2012)^{17}\end{array}$ & $\begin{array}{c}\text { Automobil } \\
\text { accident }\end{array}$ & Pneumothorax & $\begin{array}{l}\text { Pneumorrachis of the } \\
\text { cervicothoracal region }\end{array}$ & None & None & Resolution \\
\hline $\begin{array}{l}\text { Ghafarzad et } \\
\text { al. }(2014)^{18}\end{array}$ & $\begin{array}{l}\text { Motor vehicle } \\
\text { accident }\end{array}$ & $\begin{array}{l}\text { Ribs fracture, hemothorax, } \\
\text { pneumothorax, lumbal } \\
\text { vertebra fracture in L2-4 }\end{array}$ & $\begin{array}{l}\text { Pneumocephalus and } \\
\text { pneumorrachis of the } \\
\text { lumbal region L2-L4 }\end{array}$ & $\begin{array}{l}\text { Low back pain } \\
\text { and dysopena }\end{array}$ & $\begin{array}{l}\text { Laminectomy and cord } \\
\text { compression } \\
\text { Oxygen }\end{array}$ & Resolution \\
\hline $\begin{array}{l}\text { Kaloregrakos } \\
\text { et al. }(2017)^{19}\end{array}$ & $\begin{array}{l}\text { Motor vehicle } \\
\text { accident }\end{array}$ & $\begin{array}{l}\text { Ribs fracture, } \\
\text { hematopneumothorax, T10 }\end{array}$ & $\begin{array}{l}\text { Pneumorrachis of the } \\
\text { thoracolumbal region }\end{array}$ & $\begin{array}{l}\text { Right-sided } \\
\text { chest pain }\end{array}$ & Thest tube insertion & Resolution \\
\hline Present case & Fall & Rib fractures 4-9 left side & $\begin{array}{l}\text { Subcutaneus Emphysema } \\
\text { and Pneumorrachis } \\
\text { C6-T3 }\end{array}$ & None & $\begin{array}{l}\text { Shaft Clipping and chest } \\
\text { tube }\end{array}$ & Resolution \\
\hline
\end{tabular}

due to infective, degenerative, malignancy, and inflammation. ${ }^{29}$ The management of this case was done conservatively while the treatment was focused on correcting the underlying or primary cause, thus the ribs fracture with shaft clipping. Other studies also reported that pneumorrachis could be managed conservatively. In concordance with this study, penumorachis will resolve spontaneously by diffusion. ${ }^{30}$ In most cases, air tend to reabsorbs completely into the blood without significant recurrence.

The present report aimed to increase awareness about the possi- bility of pneumorrachis occurence, especially in traumatic pneumothorax. Although it was asymptomatic and self-limiting, the presence should alert the attending physician to pay more attention, by treating the underlying cause before it leads to neurologic deficits.

\section{Conclusion}

Pneumorrachis was mostly found accidentally with variety of underlying disease, especially in the case traumatic pneumothorax and fracture of skull base. Pneumorrachis was managed conservatively 
and should be taken in attention in the presence of neurologic deficits.

\section{Acknowledgement}

None.

\section{References}

1. Gordon IJ, Hardman DR. The traumatic pneumomyelogram. A previously undescribed entity. Neuroradiology. 1977;13(2):107-8. DOI: 10.1007/BF00339843.

2. Oertel MF, Korinth MC, Reinges MHT, et al. Pathogenesis, diagnosis and management of pneumorrhachis. Eur Spine J. 2006;15(5):636-43. DOI: $10.1007 / \mathrm{s} 00586-006-0160-6$.

3. Chaichana KL, Pradilla G, Witham TF, et al. The clinical significance of pneumorrachis: a case report and review of the literature. J Trauma. 2010;68(3):736-44. DOI: 10.1097/TA/0b013e3181c46dd3.

4. Belotti EA, Rizzi M, Rodoni-Cassis P, et al. Air within the spinal canal in spontaneous pneumomediastinum. Chest. 2010;137(5):1197-200. DOI: 10.1378/chest.09-0514.

5. Charlotte G, Chah'era K, Jean-François C, et al. Spontaneous Pneumomediastinum Associated with Pneumorrachis. Am J Respir Crit Care Med. 2014:189:11-9. DOI: 10.1164/rccm.201305-0900IM.

6. Newbold RG, Wiener MD, Vogler JB, et al. Traumatic pneumorrachis AJR Am J Roentgenol. 1987;148:615-6. DOI: 10.2214/ajr.148.3.615.

7. Yip L, Sweeny PJ, Mccarroll KA. The traumatic air myelogram $A m$ J Emerg Med. 1990;8(4):332-4. DOI: 10.1016/0735-6757(90)90089-I.

8. Sinha PA, Mantle M. Cervical pneumorrachis. Clin Radiol. 2000;55:56970. DOI: $10.1053 /$ crad.1999.0099.

9. Inamasu J, Nakamura Y, Saito R, et al. Air in the spinal canal after skull base fracture. Am J Emerg Med. 2002;20(1):64-5. DOI: 10.1053/ ajem.2001.29554.

10. Cayli SR, Koçak A, Kutlu R, et al. Spinal pneumorrachis. Br J Neurosurg. 2003;17(1):72-4. DOI: 10.3109/02688690309177976.

11. Yousaf I, Flynn P, McConnell R. Symptomatic intraspinal pneumocoele resulting from closed head injury. Br J Neurosurg. 2003;17(3):248-9. DOI: 10.1080/0268869031000153143

12. Chibbaro S, Selem M, Tacconi L. Cervieothoracolumbar pneumorrachis. Case report and review of the literature. Surg Neurol. 2005;64(1):80-2. DOI: 10.1016/j.surneu.2004.09.047.

13. Arora S, Aggarwal P, Cheema GS, et al. Pneumorrachis of the cervical spine with associated pneumocephalus and subcutaneous emphysema. Indian J Orthop. 2011;45(4): 372-5. DOI: 10.4103/0019-5413.82346.

14. Yanagawa Y, Takasu A, Suguira T, et al. A case of cervical pneumorrhachis induced by the combination of pneumomediastinum and root avilsion injuries. Eur Spine J. 2007;16(4): 573-4. DOI: 10.1007/s00586006-0236-3.

15. Pangtey GS, Das CJ, Javan N. Airlessness in airspace. Simultaneous occurrence of spontaneous pneumothorax with pneumomediastinum. Surg Today. 2008;38(1):49-51. DOI: 10.1007/s00595-007-3556-y.
16. Ould-Slimane M, Ettori A, Lazennec JY, et al. Pneumorrachis: a possible source of traumatic cord compression. Orthopaedics \& Traumatology: Surgery \& Research. 2010;96(7): 825-8. DOI: 10.1016/j. otsr.2010.03.024.

17. Botchu R, Shah R, Burli P. Epidural emphysema following blunt trauma: A case report and review of literature. Iowa Orthop J. 2012; 32: 224-6. Available at: https://www.ncbi.nlm.nih.gov/pmc/articles/PMC3565407/ pdf/IOJ_2012_224.pdf

18. Ghafarzad A, Tagizadieh A, Moharamzadeh P, et al. Thoracic Pneumorrhachis in Patient with Lumbar Fractures; a Case Report. Emerg. 2014 Spring;2(2):98-100. Ayailable at: https://www,ncbi.nlm.nih.gov/pmc/ articles/PMC4614588/pdf/emerg-2-098.pdf

19. Kalgoreakos PD, Lazopoulos G, Palioudakis S, et al. Pneumorrachis associated with persistent tachycardia after blunt thoracic trauma. Asian Cardiovascular \& Thoracic Annals. 2017;0(0):1-3. DOI: $10.1177 / 0218492317717421$

20. Gonzales GR, Payne R, Portenoy RK. Epidural air from a bronchop(2) leural-epidural-cutaneous fistula producing reversible myelopathy and radiculopathy symptoms. Neurology. 1994;44:2409-10. DOI: 10.1212/ wnl.44.12.2409.

21. Goh BK, Yeo AW. Traumatic pneumorrhachis. J Trauma. 2005;58:8759. DOI: 10.1097/01.TA.0000158249.77176.9A.

22. Dwarkanath S, Banerji A, Chandramouli BA. Post-traumatic intradural pneumorrhachis: A rare entity Indian J Neurotrauma 2009;6:151-2. DOI: 10.1016/S0973-0508(09)80012-9.

23. Manden PK, Siddiqui AH. Pneumorrhachis, pneumomediastinum, pneumopericardium and subcutaneous emphysema as complications of bronchial asthma. AnnThorac Med. 2009;4:143-8. DOI: 10.4103/18171737.53352.

24. Krasoudakis A, Marathianos S, Tsiminikakis N, et al. Intraspinal air after blunt thoracic trauma. J Indian Assoc Pediatr Surg. 2006;11:248-9. DOI: 10.4103/0971-9261.29612.

25. Al-Mufarej F, Gharagozloo F, Tempesta B, et al. Spontaneous cervicothoracolumbar pneumorrhachis, and pneumoperitoneum. Clin Respir J. 2009;3(4):239-43. DOI: 10.1111/j.1752-699X.2008.00116.x.

26. Ristagno RL, Hiratzka LF, Rost RC Jr. An unusual case of pneumorrhachis following resection of lung carcinoma. Chest. 2002;121:1712-4. DOI: $10.1111 /$ j.1752-699X.2008.00116.x.

27. Lerner DJ, Potturi N, Beteselassie N, et al. Pneumorrhachis. Kansas

5 Journal of Medicine. 2014;171-5. DOI: 10.17161/kjm.v7i4.11508.

28. Prabhakar H, Bithal PK, Ghosh I, et al. Pneumorrhachis presenting as quadriplegia following surgery in the prone position. Br J Anaesth. 2006;97:901-3. DOI: 10.1093/bja/ael305.

29. Adams MT, Nadalo L, Dunn EL. Air in the spinal canal following blunt thoracic trauma. J Trauma. 2003;55(2):386. DOI: 10.1097/01. TA.0000037744.83060.51.

30. Aribas OK, Gormus N, Kiresi DA. Epidural emphysema associated with primary spontaneous pneumothorax. Eur J Cardiothorac Surg. 2001;20:645-6. DOI: 10.1016/S1010-7940(01)00851-X.

Articles published online under this model are officially published and can be cited and quoted using the DOI as the reference source. Neurologico Articles published online under this model are officially published and can be cited and quoted using the DOI as the reference source. Neurologico
Spinale Medico Chirurgico has a policy that changes will not be made after publication of an article without following accepted procedures for making corrections to the scientific record. The entire contents of the Neurologico Spinale Medico Chirurgico are protected under Indian and international copyrights. The Journal, however, grants to all users a free, irrevocable, worldwide, perpetual right of access to, and a license to copy, use, distribute, perform and display the work publicly and to make and distribute derivative works in any digital medium for any reasonable non-commercial purpose, subject to proper attribution of authorship and ownership of the rights. The journal also grants the right to make small numbers of printed copies for their personal non-commercial use under Creative Commons Attribution-Non commercial-Share Alike 4.0 Unported License. 